Vol. 8 (4): 717-722 (2018)

\title{
CONFIRMATION OF THE PRESENCE OF TRITHEMIS ANNULATA (ODONATA, ANISOPTERA) IN ALBANIA
}

\author{
Enilda Shkëmbi ${ }^{1 *}$, Anila Paparisto ${ }^{1}$, Bledar Pepa ${ }^{2}$, Xhuliana Qirinxhi ${ }^{3}$, Kastriot Misja ${ }^{1}$ \\ ${ }^{1}$ University of Tirana, Faculty of Natural Science, Department of Biology, Albania; \\ ${ }^{2}$ Elbasan University, Faculty of Natural Sciences, Elbasan, Albania; \\ ${ }^{3}$ University Fan S Noli, Faculty of Natural and Human Sciences, Department of Nursing, Albania; \\ *Corresponding author: Enilda Shkëmbi ${ }^{*}$, email: enilda07@gmail.com;
}

Received May, 2018; Accepted June, 2018; Published July, 2018;

DOI: https://doi.org/10.31407/ijees8410

UOI license: http://u-o-i.org/1.01/ijees/91178770

\begin{abstract}
The present paper brings the first records of Trithemis annulata (Odonata: Anisoptera: Libellulidae) in Albania. T. annulata (Palisot de Beauvois, 1807) is a widespread species in south-western Europe, in Mediterranean countries and Balkan Peninsula. Despite this widespread, this species is reported for the first time for Albania's odonatofauna. T. annulata is part of the family Libellulidae, which has the largest number of species in Albania, 19 species, belonging to 5 genera: Libellula, Orthetrum, Sympetrum, Crocothemis and Selysiothemis. Trithemis is the sixth genus to be added to the family Libellulidae and $T$. annulata is the 66-th species in the list of Odonata for Albania (Shkëmbi et al. 2016). Nine male individuals of T.annulata were captured in two expeditions conducted in summerfall 2017, in Belshi Lakes, in the central part of Albania and in Pishë-Poro, the Vjosa River Delta.
\end{abstract}

Key words: Odonata, Libellulidae, Trithemis annulata, Albania, new records 